\title{
THE ANALYSIS OF E-LEARNING SUCCESS BY USING DELONE AND MCLEAN SUCCESS MODEL (CASE STUDY: PERTAMINA UNIVERSITY)
}

\author{
Burhan Mafazi \\ Magister Sistem Informasi Universitas Gunadarma \\ burhanmafazi@gmail.com
}

\begin{abstract}
Education is a crucial thing and highly concerned all over the world. As one of the educational institutions, the university has currently applied many information systems because of several obstacles and problems. With the fast development of information and communication technology, the learning process also has improved, known as e-learning. Pertamina University is a private university located in Jakarta, which has six faculties and 15 study programs. Since its inception in 2016, Pertamina University has applied e-learning to its students. Based on the conceptual models developed by DeLone \& McLean, this research aims to examine the success of the implementation of the e-learning system in Pertamina University with six variables, which are information quality, system quality, service quality, use, user satisfaction, and net benefit. The results of the study using 610 samples showed that the information quality variable did not affect the user satisfaction variable, which means that the quality of information on e-learning needed to be improved again to get a better response to user satisfaction.
\end{abstract}

Keywords: DeLone and McLean model; E-learning; Information system success model.

\section{INTRODUCTION}

Education is a crucial thing and highly concerned all over the world. In the education arrangement, good management of education information is urgently needed to provide services for parties involved and produce better performances. Preciseness, accuracy, and the speed of information presentation are vital factors to manage and support students' academic performances. The implementation of information technology becomes a significant model to win the competition and improve the service qualities in the field of education.

As one of the educational institutions, the university has currently applied many information systems because of several obstacles and problems that often have to face. With the fast development of information and communication technology, the learning process has also improved, known as electronic learning (e-learning). With e-learning, college students can study through the internet, so it will help them to find many study sources related to the issues faced in the learning process [1]. Some research concerning the success model of using the information system [2], [3] and e-learning system [1], [4], [5] has been conducted.

There are some differences between traditional learning and e-learning. In traditional learning, lecturers are considered omniscient and charged to give knowledge to their students. College students are independent in some particular times and responsible for their learning. E-learning environments will force college students to play an active role in their learning. College Students do the planning and look for the materials by their effort as well as initiative. Many universities have used elearning, and one of them is Pertamina University.

\section{METHOD}

The success model of the information technology system developed by DeLone and McLean [2] gets responses quickly. One of its reasons is because their model is a parsimony model yet considered quite valid. Another reason is that it currently needs a model that can become the reference to make an information technology system that can be implemented successfully in institutions. 


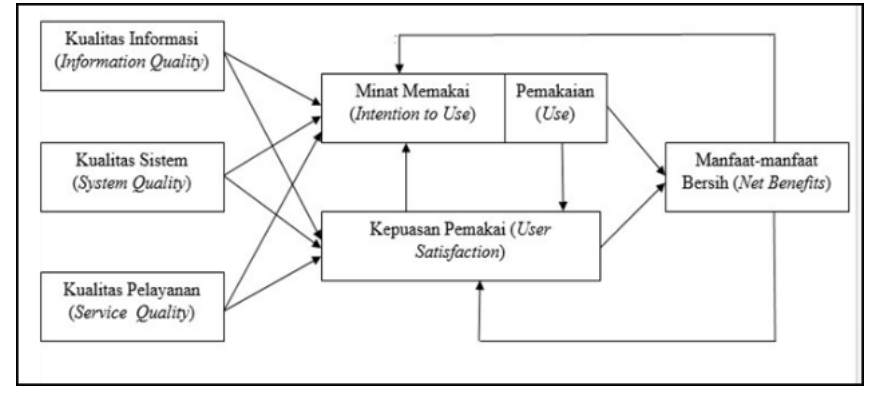

Fig 1. DeLone and McLean Model

This model was used because DeLone and McLean's model had been frequently applied to measure the system's success. Based on that model, it would be developed as the base of the research early hypothesis, which became the reference in developing a questionnaire to measure e-learning implementation success.

\section{RESULT AND DISCUSSION}

There were three independent variables and three dependent variables gained through the proposal of the early hypothesis. Independent variables are influential variables or variables that cause transformations or dependent variables [6]. On the other side, dependent variables are influenced variables or variables that exist because of independent variables. There was some early hypothesis proposed by the researcher:

H1: The Effect of System Quality on the Use

H2: The Effect of System Quality on User Satisfaction

H3: The Effect of Information Quality on the Use

H4: The Effect of Information Quality on User Satisfaction

H5: The Effects of Service Quality on the Use

H6: The Effects of Service Quality on User satisfaction

After the system quality, information quality, and service quality had been determined, then it was followed by the hypothesis that determined the relationship between the use, user satisfaction, and net benefit.

H7: The Effect of Use on User satisfaction

H8: The Effect of Use on Net Benefit

H9: The Effect of User Satisfaction on Net Benefit

\section{A. Variables and Indicators}

DeLone and McLean's Model was developed based on the theory and result of information system empirical research in the 1970s and 1980s. For ten years until 2002, nearly 300 articles in various journals cited and used this model. This model, which has been largely known, signifies strong evidence for integrating the research findings in information systems comprehensively. Things renewed to include the following:

1. Add the dimension of Service Quality as the addition of the existing dimensions of qualities, which are System Quality and Information Quality.

2. Combine the individual impact and organizational impact into one variable, which is Net Benefit. This combination aims to keep the model remaining parsimony.

3. Add the dimension of Intention using Intention to Use as the alternative dimension of Use. DeLone and McLean [7] propose an alternative measure, which is the Intention of Use. The intention of use is the attitude, while Use is the Behavior.

4. Use and User Satisfaction are strongly connected. Use must precede User satisfaction as the process. However, a positive experience because of the Use will make User Satisfaction higher as the causal.

5. If the Net Benefit is positive, the Intention of Use, Use, and User Satisfaction will increase. This feedback is still valid, even when the Net Benefit is negative.

6. Model renewed has purposed to demonstrate the relation proposed by the success dimensions in the process. However, it does not signifies either a positive or negative relation is causal.

\section{B. Sample Measurement}

The process of taking representative samples was conducted using a particular measurement. There are many formulas to measure the minimum number of samples in the research. One of the formulas used in this research was Slovin. Slovin Formula was applied to determine the minimum number of samples $(n)$, if the number of population $(N)$ in the significance level $(\alpha)$, it showed that:

$$
n=\frac{N}{1+N e^{2}}
$$


Note:

$\mathrm{n}=$ The number of the samples

$\mathrm{N}=$ The number of all population members

$\mathrm{e}=$ Significance Level (fault tolerance; 0,05 )

In this research, the research population was 5000 students of Pertamina University that would be represented as $\mathrm{N}$, while the level of fault samples chosen was $5 \%$, so the measurement as follow:

$$
\begin{aligned}
& n=\frac{5000}{1+5000(0.05)^{2}} \\
& n=370,3703
\end{aligned}
$$

The result of the measurement using the Slovin formula above was 370 (roundup) students involved as the minimum sample needed in this research to represent the student population's characteristics in Pertamina University.

\section{Analysis of Structural Equation Modelling (SEM)}

Analysis of Structural Equation Modelling (SEM) in this research used the help of SmartPLS 3 software. The following was the SEM model of the indicators in every variable that used SmartPLS 3 from the questionnaire data gained.

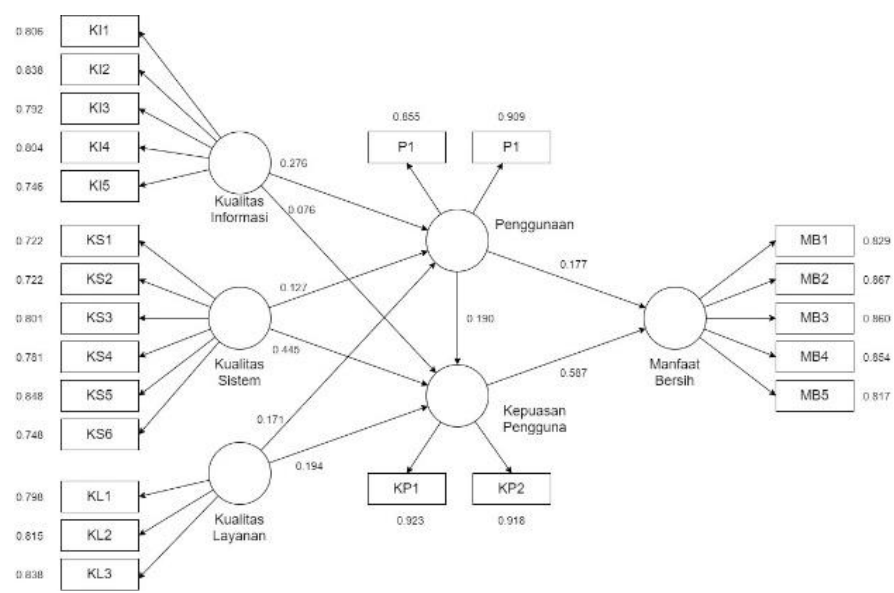

Fig 2. Structural Equation Modelling Model

Figure 2 model showed that the value of the loading factor in every indicator met the requirement, which was $\geq 0,4$, with the lowest value of loading factor had by KS1 and KS2 indicators that pointed out 0,722.

\section{Research Hypothesis Testing}

The bootstrapping test aimed to conduct hypothesis testing in the research. Here was the table of the testing result by using the Bootstrapping method.

TABLE I

Hypothesis Testing (Path Coefficient)

\begin{tabular}{|c|c|c|c|c|c|}
\hline & $\begin{array}{c}\text { Original } \\
\text { Sample }\end{array}$ & $\begin{array}{c}\text { Sample } \\
\text { Mean }\end{array}$ & $\begin{array}{c}\text { Standard } \\
\text { Deviation }\end{array}$ & $\begin{array}{c}\text { T } \\
\text { Statistics }\end{array}$ & P Values \\
\hline $\mathrm{KI}>\mathrm{P}$ & 0,276 & 0,277 & 0,059 & 4,676 & 0,000 \\
\hline $\mathrm{KI}>\mathrm{KP}$ & 0,076 & 0,074 & 0,046 & 1,662 & 0,097 \\
\hline $\mathrm{KS}>\mathrm{P}$ & 0,127 & 0,129 & 0,059 & 2,168 & 0,031 \\
\hline $\mathrm{KS}>\mathrm{KP}$ & 0,445 & 0,446 & 0,049 & 9,098 & 0,000 \\
\hline $\mathrm{KL}>\mathrm{P}$ & 0,171 & 0,168 & 0,063 & 2,707 & 0,007 \\
\hline $\mathrm{KL}>\mathrm{KP}$ & 0,194 & 0,195 & 0,051 & 3,779 & 0,000 \\
\hline $\mathrm{P}>\mathrm{KP}$ & 0,190 & 0,189 & 0,032 & 5,896 & 0,000 \\
\hline $\mathrm{P}>\mathrm{MB}$ & 0,177 & 0,174 & 0,037 & 4,718 & 0,000 \\
\hline $\mathrm{KP}>\mathrm{MB}$ & 0,587 & 0,590 & 0,038 & 15,543 & 0,000 \\
\hline
\end{tabular}

In Table 1 above, it showed nine results of hypothesis testing that had been conducted as follow:

1. The relation between Information Quality toward The Use

H0: There were no relations between Information Quality toward the Use

H1: There were relations between Information Quality toward the Use

The relationship between Information Quality and Usage has a $\mathrm{T}$ Statistics value of 4,676 which means $\geq 1,96$. And the Original Sample value is a positive value of 0,276 which indicates the relationship between the two is positive, while the $\mathrm{P}$ Values is $0,000 \leq 0,05$.

2. The relation between Information Quality toward User Satisfaction

H0: There were no relations between Information Quality toward User Satisfaction H1: There were no relations between Information Quality toward User Satisfaction The relationship between Information Quality and User Satisfaction has a T Statistics value of 1,662 , which means $\leq 1,96$. And the Original Sample value is a positive value of 0,076 which shows the relationship between the two is positive, while the $P$ Values is $0,097 \geq 0,05$.

3. The relation between System Quality toward the Use 
H0: The were no relations between System Quality toward the Use

H1: The were relations between System Quality toward the Use

The relationship between System Quality and Usage has a T Statistics value of 2,168, which means $\geq 1,96$. And the Original Sample value is a positive value of 0,127 which indicates the relationship between the two is positive, while the $\mathrm{P}$ Values is $0,031 \geq 0,05$.

4. The relation between System Quality toward User Satisfaction

H0: The were no relations between System Quality toward the User Satisfaction

H1: The were relations between System Quality toward the User Satisfaction

The relationship between System Quality and User Satisfaction has a $\mathrm{T}$ Statistics value of 9,098 , which means $\geq 1.96$. And the Original Sample value is a positive value of 0,445 which shows the relationship between the two is positive, while the $\mathrm{P}$ Values is $0,000 \leq 0,05$.

5. The relation between Service Quality toward the Use

H0: The were no relations between Service Quality toward the Use

H1: The were relations between Service Quality toward the Use

The relationship between Information Quality and Usage has a T Statistics value of 2,707 which means $\geq 1,96$. And the Original Sample value is a positive value of 0,171 which indicates the relationship between the two is positive, while the $\mathrm{P}$ Values is $0,007 \leq 0,05$.

6. The relation between Service Quality toward User Satisfaction

H0: The were no relations between Service Quality toward User Satisfaction

H1: The were relations between Service Quality toward User Satisfaction

The relationship between Service Quality and User Satisfaction has a $\mathrm{T}$ Statistics value of 3,779 which means $\geq 1,96$. And the Original Sample value is a positive value of 0,194 which indicates the relationship between the two is positive, while the $\mathrm{P}$ Values is $0,000 \leq 0,05$.
7. The relation between the Use toward User Satisfaction

H0: The were no relations between the Use toward User Satisfaction

H1: The were relations between the Use toward User Satisfaction

The relationship between Usage and User Satisfaction has a T Statistics value of 5,896, which means $\geq 1,96$. And the Original Sample value is a positive value of 0,190 which shows the relationship between the two is positive, while the $P$ Values is $0,000 \leq 0,05$.

8. The relation between the Use toward Net Benefit $\mathrm{H} 0$ : The were no relations between the Use toward Net Benefit

H1: The were relations between the Use toward Net Benefit

The relationship between Usage and Net Benefits has a T Statistics value of 4,718, which means $\geq 1,96$. And the Original Sample value is a positive value of 0,177 which indicates the relationship between the two is positive, while the $\mathrm{P}$ Values is $0,000 \leq 0,05$.

9. The relation between User Satisfaction toward Net Benefit

H0: The were no relations between User Satisfaction toward Net Benefit

H1: The were relations between User Satisfaction toward Net Benefit

The relationship between User Satisfaction with Net Benefits has a T Statistics value of 15,543, which means $\geq 1,96$. And the Original Sample value is a positive value of 0,587 which shows the relationship between the two is positive, while the $\mathrm{P}$ Values is $0,000 \leq 0,05$.

\section{E. R-Square $\left(R^{2}\right)$ Testing}

R-Square test was applied to know how much the relation of some variables. The higher the value of $\mathrm{R}^{2}$, the better the prediction model of the research model proposed. The classifications of the value of $\mathrm{R}^{2}$ were $\geq 0,67$ (strong), 0,33-0,66 (moderate), and $0,19-0,32$ (weak) [8]. 
TABLE II

The value of R-Square and Adjusted R-Square

\begin{tabular}{|l|c|c|}
\hline \multicolumn{1}{|c|}{ Variables } & R Square & Adjusted \\
\hline User satisfaction & 0,601 & 0,598 \\
\hline Net Benefit & 0,483 & 0,481 \\
\hline Use & 0,270 & 0,267 \\
\hline
\end{tabular}

Adjusted R-Square was the value of R-Square adjusted, this value was always smaller from the $\mathrm{R}$ square, and the number could have negative values.

\section{F. The goodness of Fit Testing}

After gaining Average Variance Extracted (AVE) and Adjusted R-Square $\left(\mathrm{R}^{2}\right)$ values, the next step was to measure the Goodness of Fit $(\mathrm{GoF})$. The range values of GoF were 0-1, with the agreement of GoF $>0,1$ (bad), GoF > 0,25 (moderate), dan GoF > 0,36 (good) (Haryono, 2017).

TABLE III

The Value of Goodness of Fit

\begin{tabular}{|l|c|c|}
\hline \multicolumn{1}{|c|}{ Variable } & GoF & Note \\
\hline User satisfaction & 0,711 & Good \\
\hline Net Benefit & 0,586 & Good \\
\hline Use & 0,456 & Good \\
\hline
\end{tabular}

\section{G. The Result of Research Analysis}

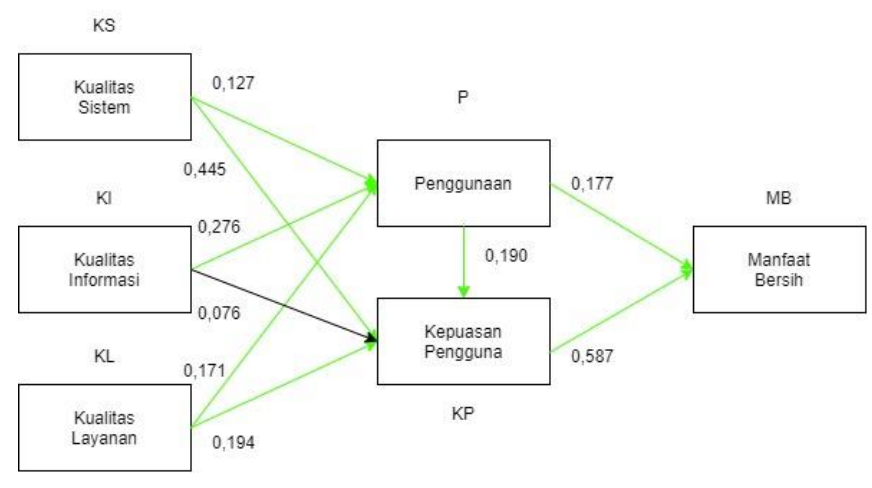

Fig 3. The Levels of Effect among Variables

The result gained through this research was the level of DeLone and McLean model success. Here was the DeLone and McLean model success that signified the level of the effect of variable among the variables.

1. Information Quality variables had a positive effect on the Use variables, so if there were value changes in Information Quality variables, it would affect the Use variables.

2. Information Quality variables did not have a positive effect on the User Satisfaction variables, so if there were value changes in Information Quality variables, it would not affect the User Satisfaction variables.

3. System Quality variables had a positive effect on the Use variables, so if there were value changes in System Quality variables, it would affect the Use variables.

4. System Quality variables had a positive effect on the User Satisfaction variables, so if there were value changes in System Quality variables, it would affect the User Satisfaction variables.

5. Service Quality variables had a positive effect on the Use variables, so if there were value changes in Service Quality variables, it would affect the Use variables.

6. Service Quality variables had a positive effect on the User Satisfaction variables, so if there were value changes in Service Quality variables, it would affect the User Satisfaction variables.

7. Use variables had a positive effect on the User Satisfaction variables, so if there were value changes in Use variables, it would affect the User Satisfaction variables.

8. Use variables had a positive effect on the Net Benefit variables, so if there were value changes in Use variables, it would affect the Net benefit variables.

9. User Satisfaction variables had a positive effect on the Net Benefit variables, so if there were value changes in User Satisfaction variables, it would affect the Net benefit variables.

\section{CONCLUSION}

Based on the analysis and the discussion conducted earlier, the researcher concluded building upon this research's aims, that the DeLone and McLean Success Model factors showed that only the Information Quality did not affect the User Satisfaction variables. It pointed out that Information 
Quality in e-learning needed to be improved to gain better user satisfaction responses.

\section{REFERENCES}

[1] Y.-S. Wang, H.-Y. Wang, and D. Y. Shee, "Measuring elearning systems success in an organizational context: Scale development and validation," Comput. Human Behav., vol. 23, no. 4, pp. 1792-1808, Jul. 2007, doi: 10.1016/j.chb.2005.10.006.

[2] W. H. DeLone and E. R. McLean, "Information Systems Success: The Quest for the Dependent Variable," Inf. Syst. Res., vol. 3, no. 1, pp. 60-95, Mar. 1992, doi: 10.1287/isre.3.1.60.

[3] A. Rai, S. S. Lang, and R. B. Welker, "Assessing the Validity of IS Success Models: An Empirical Test and Theoretical Analysis," Inf. Syst. Res., vol. 13, no. 1, pp. 50-69, Mar. 2002, doi: 10.1287/isre.13.1.50.96.

[4] D. Zhang and J. F. Nunamaker, "Powering e-learning in the new millennium: an overview of e-learning and enabling technology," Inf. Syst. Front., vol. 5, no. 2, pp. 207-218, 2003.

[5] A. Lee-Post, "e-Learning Success Model: An Information Systems Perspective.," Electron. J. e-learning, vol. 7, no. 1, pp. 61-70, 2009.

[6] D. Sugiyono, Metode Penelitian Kuantitatif Kualitatif dan $R \& D$. Bandung: Penerbit Alfabeta, 2010.

[7] W. H. Delone and E. R. McLean, "The DeLone and McLean Model of Information Systems Success: A TenYear Update," J. Manag. Inf. Syst., vol. 19, no. 4, pp. 930, Apr. 2003, doi: 10.1080/07421222.2003.11045748.

[8] S. Haryono, "Metode SEM untuk Penelitian Manajemen AMOS Lisrel PLS," Jakarta: Luxima Metro Media, 2017. 